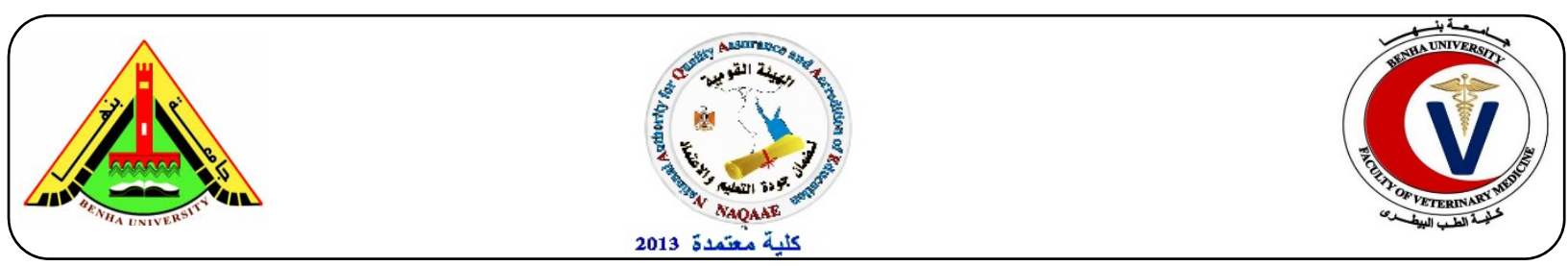

\title{
Antibacterial resistance and resistance gene detriments of E.coli isolated from chicken.
}

\author{
Ashraf A. Abd El Tawab ${ }^{1}$, Ahmed M. Ammar' ${ }^{2}$, Soad A. Nasef ${ }^{3}$, Reem M. Reda ${ }^{3}$ \\ ${ }^{1}$ Department of Bacteriology, Immunology and Mycology, Faculty of Veterinary Medicine, Benha \\ University. ${ }^{2}$ Department of Bacteriology, Immunology and Mycology, Faculty of Veterinary Medicine, \\ Zagazig University. ${ }^{3}$ Reference Laboratories for Veterinary Quality Control on Poultry Production, \\ Dokki, Giza.
}

\begin{abstract}
A B S T R A C T
A total of 30 isolate of E.coli isolated from diseased chicken belonged to different serotypes. All isolate showed resistance to one or more antibiotics by disc diffusion methods. They were investigated against 6 antibiotics from different groups the result were, gentamicin about $46.6 \%$, erythromycin $63.3 \%$, tetracycline $80 \%$, ciprofloxacin $40 \%$, ampicellin $73.3 \%$ and florfenicol $53 \% .3$. Detection of resistance genes by PCR test relieved negative result in all isolated to detected $a a c\left(6^{\prime}\right)-I b-c r$ gene, while 22 isolate out of 30 examined E.coli isolate were carried the blaTEM gene on anther hand floR gene was detected in $29(96 \%)$ of E.coli isolate. Also tetA (A) gene was found in $22(73 \%)$ of E.coli isolate out of 30 examined isolate. On another hand $a a d \mathrm{~B}$ (gentamicin resistance gene) gene was present in $8(26 \%)$. $11(36 \%)$ of E.coli isolate were carried the $m p h(A)$ erythromycin resistance gene .Correlation between the presence of resistance gene and the resistance to antibiotics were recorded.
\end{abstract}

Keywords: E.coli, Resistance gene, Disc diffusion method, PCR.

(http://www.bvmj.bu.edu.eg) conference issue

(BVMJ-28(2): 231-240, 2015)

\section{INTRODUCTION}

$\longrightarrow$ scherichia coli are a normal inhabitant of the gastrointestinal tract of humans and animals; however, some strains are known to be pathogenic. These strains induce colibacillosis in chicken, which is an important cause of economic losses for the poultry industry (Amara et al., 1995). It is one of the most important and frequently encountered bacterial avian pathogen causing a wide variety of disease syndrome in birds causing up to $30 \%$ of mortality in poultry (Kaul et al., 1992, Barnes and Gross 1997 and Geornaras et al., 2001). Colibacillosis refers to any localized or systemic infection caused entirely or partly by avian pathogenic Escherichia coli (APEC), including colisepticemia, coligranuloma (Hjarre's disease), air sac disease (chronic respiratory disease, CRD), cellulites (inflammatory process), swollen head syndrome, peritonitis, salpingitis, osteomyelitis/synovitis (turkey osteomyelitis complex), panophthalmitis and omphalitis/yolk sac infection (Saif, 2003). Concern about antibiotic resistance and its transmission to human pathogens is important because these resistant bacteria may colonize the human intestinal tract and may also contribute resistance genes to human endogenous flora. Colonization of the intestinal tract with resistant $E$. coli from chicken has been shown in human volunteers (Linton et al., 1977). The result of a study done by Van den Bogaard et al., (2001) strongly indicated that transmission of resistant clones and resistance plasmids of E.coli from poultry to humans commonly occurs (Van den Bogaard et al., 2001). Furthermore, in some previous studies, 
spread of an antibiotic resistance plasmid, pSL222-6, in E.coli from chickens to human (Levy et al., 1976), direct transmission of $E$. coli resistant to streptomycin, sulphonamides and tetracycline from poultry to poultry attendants in Nigeria (Ojeniyi, 1985; Ojeniyi, 1989), recorded that evidence that animals were a reservoir for E.coli found in humans (Cooke, 1971), chickens as a source of antibiotic resistance in humans in Saudi Arabia, Morocco and northern India (Singh et al., 1992; Amara et al., 1995; and Al Ghamdi et al., 1999 ) was described. The aim of this work was the detection of the resistant antibiotic gene by PCR techniques and correlation with resistant to antibiotics.

\section{MATERIAL AND METHODS}

\subsection{Chicken samples}

A total of 30 isolates of $E$. coli isolated from diseased chickens was taken from the culture collection of the Central Laboratory for Veterinary Quality Control on Poultry Production, Dokki. The E. coli isolates were recovered from different organs (liver, lung, yolk sac and bone marrow) of chickens that suffered from colisepticaemia. The isolates belonged to different O-serogroups and showed resistance to one or more antibiotics.

\subsection{Antimicrobial sensitivity}

The disk diffusion technique was applied according to (Cruickshank et al., 1975).Six antibacterial sensitivity discs was used as florfenicol, ciprofloxacin, tetracycline, erythromycin, gentamicin and ampicillin.

\subsection{Detection of resistance genes using Polymerase chain reaction (PCR)}

Oligoneucleotide primers were designated according to Integrated DNA Technology. The primers sequences were illustrated as in Table (1).

\subsubsection{DNA extraction and purification}

The extraction was done by QIAamp ${ }^{\circledR}$ DNA MiniKit (Cat. No. 51304, Qiagen) used according to manufacturer's instructions.

\subsubsection{Amplification and cycling protocol for conventional PCR}

Using of PCR 1.1x ReddyMix TM Master Mix (Thermo SCIENTIFIC) with Cat. No. AB0575/LD-A.

\subsubsection{Detection of PCR products:} (Sambrooket al., 1989)

Aliquots of amplified PCR products were mixed with gel loading buffer and electrophoresed in 1.5\% agarose gel.

Table (1) Cycling conditions of the different primers during PCR

\begin{tabular}{|c|c|c|c|}
\hline Primer & Sequence(5'- 3') & $\begin{array}{l}\text { Amplified } \\
\text { product }\end{array}$ & Reference \\
\hline $\operatorname{tet} A(A)$ & $\begin{array}{l}\text { GGTTCACTCGAACGACGTCA } \\
\text { CTGTCCGACAAGTTGCATGA }\end{array}$ & 576 bp & $\begin{array}{l}\text { Randall et al. } \\
2004\end{array}$ \\
\hline $\operatorname{aadB}$ & $\begin{array}{l}\text { GAGCGAAATCTGCCGCTCTGG } \\
\text { CTGTTACAACGGACTGGCCGC }\end{array}$ & $319 \mathrm{bp}$ & Franaet al., 2001 \\
\hline$b a_{T E M}$ & $\begin{array}{l}\text { ATCAGCAATAAACCAGC } \\
\text { CCCCGAAGAACGTTTTC }\end{array}$ & $516 \mathrm{bp}$ & $\begin{array}{l}\text { Colom et al., } \\
2003\end{array}$ \\
\hline $\begin{array}{l}a a c\left(6^{\prime}\right)-I b- \\
c r\end{array}$ & $\begin{array}{l}\text { CCCGCTTTCTCGTAGCA } \\
\text { TTAGGCATCACTGCGTCTTC }\end{array}$ & $113 \mathrm{bp}$ & Lunnet al., 2010 \\
\hline$m p h(A)$ & $\begin{array}{l}\text { GTGAGGAGGAGCTTCGCGAG } \\
\text { TGCCGCAGGACTCGGAGGTC }\end{array}$ & $403 \mathrm{bp}$ & $\begin{array}{l}\text { Nguyen et al., } \\
2009\end{array}$ \\
\hline floR & $\begin{array}{l}\text { TTTGGWCCGCTMTCRGAC } \\
\text { SGAGAARAAGACGAAGAAG }\end{array}$ & $494 \mathrm{bp}$ & $\begin{array}{l}\text { Doubletet al., } \\
2003\end{array}$ \\
\hline
\end{tabular}

tetA(A): tetreacyclin, aadB: gentamicin bla ${ }_{\mathrm{TEM}}$ : ampicilin, aac(6')-Ib-crciprofloxacin, $\mathrm{mph}(\mathrm{A})$ :erythromycin, floR: florfenicol 


\section{RESULTS}

\subsection{Antibiotic sensitivity of E.coli strains}

It clears that the highest rate of resistance was shown against tetracycline group of Antibiotic, where about $80 \%$ of isolate were resistant, followed by the $\beta$-lactam antibiotic (ampicillin) $73.3 \%$ followed by erythromycin about $63.3 \%$ of tested isolate were resistant, florfenicol about $53.3 \%$ of isolate were resistance, gentamicin is about $46.6 \%$ of isolate were resistance, finally ciprofloxacin about $40 \%$ of tested isolate were resistant (Table 2).

Table (2) Result of antibiotics resistance of E.coli by disc diffusion method

\begin{tabular}{|c|c|c|c|c|c|c|c|}
\hline Isolate & $\mathrm{G}$ & $\mathrm{E}$ & $\mathrm{T}$ & $\mathrm{C}$ & A & $\begin{array}{l}\mathrm{A} \\
\mathrm{M}\end{array}$ & $\begin{array}{l}\text { FF } \\
\mathrm{C}\end{array}$ \\
\hline Sensitive & 10 & 7 & 4 & $\begin{array}{l}1 \\
0\end{array}$ & 4 & 5 & 9 \\
\hline $\begin{array}{l}\text { Intermitt } \\
\text { ent }\end{array}$ & 6 & 4 & 2 & 8 & 4 & 3 & 5 \\
\hline $\begin{array}{l}\text { Resistan } \\
\text { ce }\end{array}$ & 14 & 19 & $\begin{array}{l}2 \\
4\end{array}$ & $\begin{array}{l}1 \\
2\end{array}$ & 22 & 22 & 16 \\
\hline$\% *$ & $\begin{array}{l}46 . \\
6\end{array}$ & $\begin{array}{l}63 . \\
3\end{array}$ & $\begin{array}{l}8 \\
0 \\
\end{array}$ & $\begin{array}{l}4 \\
0 \\
\end{array}$ & $\begin{array}{l}73 . \\
3\end{array}$ & $\begin{array}{l}73 . \\
3\end{array}$ & $\begin{array}{l}53 . \\
3\end{array}$ \\
\hline
\end{tabular}

\subsection{PCR for Detection of resistance Genes of E.coli}

PCR using primers fragments listed in materials and methods for amplification of tet $\mathrm{A}(\mathrm{A})$ tetreacyclin, aad $\mathrm{B}$ gentamycin, bla TEM ampicilin, aac (6')-Ibcrciprofloxacin, $m p h(\mathrm{~A})$ erythromycin, and floR flourofinicol from the isolated E.coli strains in this study.

\subsubsection{Detection of aac(6,)-Ib-cr gene of E.coli}

Quinolones (ciprofloxacin) act by binding to gyrase/topoisomerase IV-DNA complex. Formation of quinolone gyrase/ topoisomerase IV-DNA complex is responsible for the inhibition of DNA replication. Our results showed in figure (1) that all isolate were negative to $a a c(6)-I b$ cr gene.

\subsubsection{Detection of blaTEM gene of E.coli}

The mechanism of action of $\beta$-lactams is to disrupt bacterial cell wall synthesis by linking covalently to enzymes, i.e. penicillin-binding proteins. Our results showed amplification at 516bpas showed in figure (2).

\subsubsection{Detection of floR gene of E.coli}

Florfenicol prevent protein chain elongation by inhibiting the peptidyl transferase activity of the bacterial ribosome. Our results showed amplification at 494bpas showed in figure (3).

Table (3): Result of PCR of different resistance gene

\begin{tabular}{|c|c|c|c|c|c|c|c|}
\hline $\begin{array}{l}\text { Samp } \\
\text { le }\end{array}$ & $\begin{array}{c}\mathrm{O} \\
\text { grou } \\
\mathrm{p}\end{array}$ & $\begin{array}{c}a a c( \\
6 I b- \\
c r\end{array}$ & $\begin{array}{c}m p h \\
A\end{array}$ & $\begin{array}{c}\text { bla } \\
E M\end{array}$ & floR & $\begin{array}{c}a a d \\
B\end{array}$ & $\begin{array}{c}\text { tet } A( \\
A)\end{array}$ \\
\hline 1 & O91 & - & + & - & + & - & - \\
\hline 2 & 0142 & - & - & + & + & - & + \\
\hline 3 & $\mathrm{O} 142$ & - & - & - & + & + & - \\
\hline 4 & O103 & - & - & - & - & - & - \\
\hline 5 & $\mathrm{O} 1$ & - & - & + & + & - & + \\
\hline 6 & $\mathrm{O} 125$ & - & - & + & + & - & + \\
\hline 7 & O144 & - & $+*$ & + & + & - & + \\
\hline 8 & $\mathrm{O} 28$ & - & - & + & + & - & + \\
\hline 9 & O158 & - & - & + & + & + & + \\
\hline 10 & O55 & - & - & + & + & + & + \\
\hline 11 & O114 & - & - & + & + & + & + \\
\hline 12 & O158 & - & - & - & + & - & + \\
\hline 13 & O159 & - & + & + & + & - & + \\
\hline 14 & O128 & - & + & - & + & - & + \\
\hline 15 & O124 & - & - & + & + & - & + \\
\hline 16 & $\mathrm{O} 125$ & - & + & + & + & - & + \\
\hline 17 & O91 & - & + & + & + & - & + \\
\hline 18 & O144 & - & + & + & + & - & + \\
\hline 19 & O125 & - & + & + & + & - & + \\
\hline 20 & O166 & - & + & + & + & - & - \\
\hline 21 & $\mathrm{O} 44$ & - & + & + & + & - & - \\
\hline 22 & O103 & - & - & + & + & + & + \\
\hline 23 & $\mathrm{O} 44$ & - & + & + & + & + & + \\
\hline 24 & $\mathrm{O} 26$ & - & - & - & + & + & - \\
\hline 25 & O103 & - & - & + & + & - & + \\
\hline 26 & O151 & - & - & + & + & + & + \\
\hline 27 & $\mathrm{O} 26$ & - & - & - & + & - & - \\
\hline 28 & O63 & - & - & + & + & - & + \\
\hline 29 & O128 & - & - & - & + & - & - \\
\hline 30 & O6 & - & - & + & + & - & + \\
\hline \multirow{2}{*}{$\begin{array}{l}\text { Pos/ } \\
\text { tested }\end{array}$} & \multirow{2}{*}{-} & \multirow{2}{*}{$0 / 30$} & $11 / 3$ & $22 / 3$ & $29 /$ & $8 / 3$ & $22 / 3$ \\
\hline & & & 0 & 0 & 30 & 0 & 0 \\
\hline \multirow{2}{*}{$\begin{array}{l}\text { Positi } \\
\text { ve } \%\end{array}$} & \multirow{2}{*}{-} & \multirow{2}{*}{-} & \multirow{2}{*}{$36 \%$} & \multirow{2}{*}{$73 \%$} & 96 & 26 & $73 \%$. \\
\hline & & & & & $\%$ & $\%$ & 0 \\
\hline
\end{tabular}

\subsubsection{Detection oftetA(A) gene of E.coli}


Tetracycline inhibits bacterial protein synthesis. Our results showed amplification at $576 \mathrm{bp}$ as showed in figure (4).

\subsubsection{Detection of aad(B) gene of E.coli}

Aminoglycoside antibiotics (gentamycin) target the ribosome to inhibit protein translation. Our results showed amplification at $319 \mathrm{bp}$ as showed in figure (5).

\subsubsection{Detection of $m p h(A)$ gene of E.coli}

Macrolide-lincosamide-streptogramin (erythromycin) classes of antibiotics target the ribosome to inhibit protein translation. Our results showed amplification at 403bp as showed in figure (6).

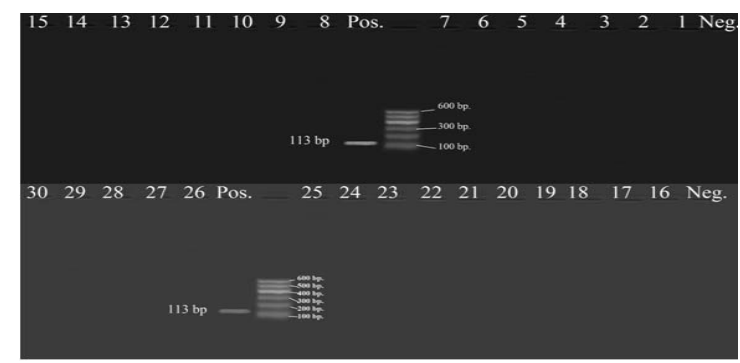

Figure (1) Agarose gel electrophoresis of products obtained by PCR for $E$. coli strains to detect gene (aac(6,)Ib-cr):lane (1-30) are negative, Pos: positive Neg: negative

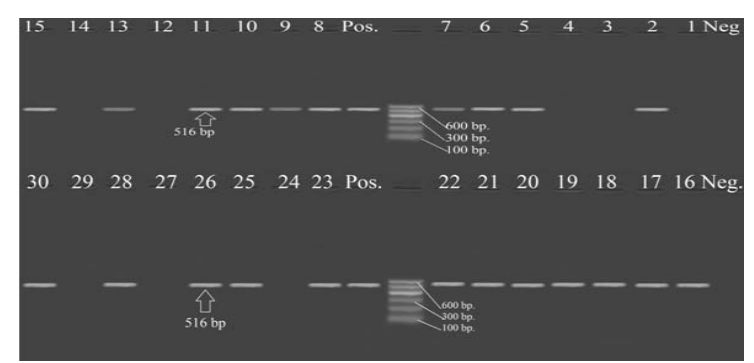

Figure(2)Agarose gel electrophoresis of products obtained by PCR for $E$. coli strains to detect gene blaTEM):lane no 2,5,6,7,8,9,10,11,13,15,16,17,18,19,20,21,22,23,25,26,28 , 30 were positive at $516 \mathrm{bp}$. Pos: positive Neg: negative.

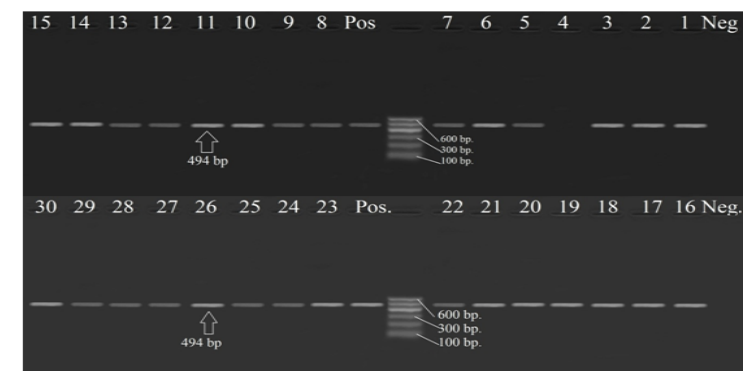

Figure(3)Agarose gel electrophoresis of products obtained by PCR for E. colistrains to detect gene( floR)all lanes were positive at 494bp except lane no(4)was negative.Pos: positive Neg: negative

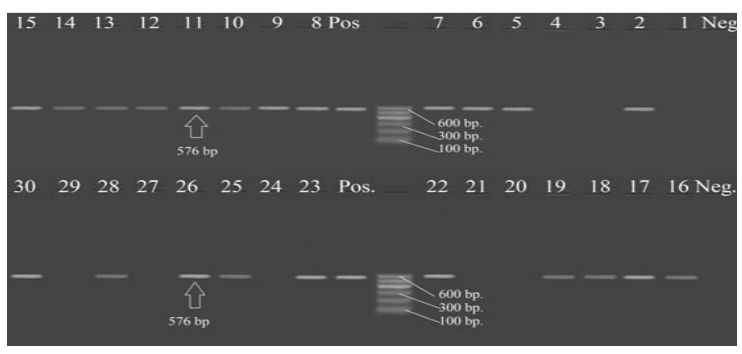

Figure(4) Agarose gel electrophoresis of products obtained by PCR for E.coli strains to detect gene (tet $\mathrm{A}):$ lane

no2,5,6,7,8,9,10,11,12,13,14,15,16,17,18,19,22,23,25,26. 28,30 were positive at $576 \mathrm{bp}$. Pos: positiveNeg: negative.

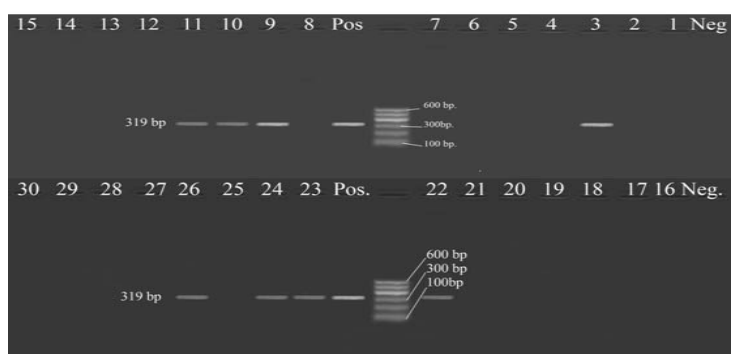

Figure(5)Agarose gel electrophoresis of products obtained by PCR for $E$. coli strains to detect gene $(a a d \mathrm{~B})$ :lane no $3,9,10,11,22,23,24,26$ at319 bp.Pos: positiveNeg: negative.

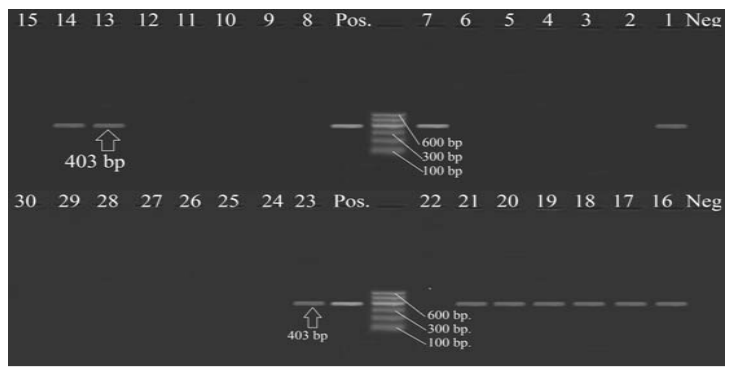

Figure(6)Agarose gel electrophoresis of products obtained by PCR for E. coli strains to detect gene $\mathrm{mph}(\mathrm{A})$ : lane no1,7.13,14,16,17,18,19,20,21,23 were positive isolate at 403 bp.Pos: positive Neg: negative.

\section{DISCUSSION}

In present study we used different antibiotics from different group of antibiotics as ciprofloxacin from quinolone, and ampicillin from $\beta$-lactemase group, also we used gentamycin from aminoglycosides antibiotic group, erythromycin from macrolide antibiotic group and florfenicol antibiotics from miscellanies antibiotics each type is act on different site of bacteria. Quinolones act by inhibiting the action of topoisomerases II (DNA gyrase) and topoisomerase IV. For Gram-negative bacteria the prime target of quinolones is the DNA gyrase, whereas in the Gram-positives it is the topoisomerase 
IV (Andriole 2005). Quinolones act by binding to gyrase/topoisomerase IV-DNA complex. Formation of quinolonegyrase/ topoisomerase IV-DNA complex is responsible for the inhibition of DNA replication and the bacteriostatic action of the quinolones while their lethal action is thought to be a separate event from complex formation, and to arise from the relapse of free DNA ends from quinolone-gyraseDNA complexes (Nordmann and Poirel, 2005).

All isolate (30) were negative to ciprofloxacin resistance gen aac $\left(6^{\prime}\right)-I b-c r$ fig(1) and table(3) that agree with Goswami et al., (2002) and Ahmed et al., (2014) on other hand, Xia et al., (2009) observed that 198 avian E.coli isolates from Shandong, China were resistant to enrofloxacin $99 \%$, ciprofloxacin $100 \%$, norfloxacin 100\%, amoxicillin/clavulanic acid 87.4\%, ampicillin 99.5\%, gentamicin $97 \%$ and amikacin $27.8 \%$. Also in present study, it was recorded that lower number of isolate was resistant to ciprofloxacin about $12(40 \%)$ of E.coli isolate which was nearly similar to that detected by Jiang et al., (2011). About $44.4 \%$ of isolate were resistant to ciprofloxacin a mange chicken E.coli strain in China. On other hand, Wang et al., (2001) found that high rates of resistance to quinolones have been reported from different parts of the world. In China, for example, more than $50 \%$ of the clinical strains of E. coli isolated during 1997-1999 were resistant to ciprofloxacin .Also Xia et al., (2009) observed that 198 avian E. coli isolates from Shandong, China were resistant to enrofloxacin $99 \%$ and ciprofloxacin $100 \%$.

Ampicillin and amoxicillin $(\alpha-$ amino penicillins), two penicillin derivates with greater acid stability and a better Gramnegative effect, were developed by Beecham. The $\beta$-lactamases are the collective name of enzymes that open the $\beta$ lactam ring by adding a water molecule to the common $\beta$-lactam bond, and this inactivates the $\beta$-lactam antibiotic from penicillin to carbapenems. This hydrolyzation was first observed in 1940 by Abraham and Chain (penicillinase) in a strain of E. coli (Abraham et al., 1940). blaTEM gene was detected in about $22(73 \%)$ of E.coli isolate fig (2) and table (3) which similar agree with results of Jiang et al ., (2011) detected $88.9 \%$ of blaTEM gene among chicken E.coli strain isolated from Shanxi, Henan and Gansue Provinces in China. Also blaTEM gene were detected by Domínguez et al., (2002) about $20(48.7 \%)$ of E.coli isolate and Brinas et al., (2003) reported three positive blaTEM PCR result from five Escherichia coli isolates, and a positive PCR result was obtained for an additional isolate which were lower than the result of this study. Also by disc diffusion $\beta$-Lactam group (ampicillin) was 73.3\% (table 2). These results agreedwithRaduet al. (2001) illustrated that all the E.coli isolates were identified as E.coli isolated from chickens. All the strains were found to be resistant to two or more of the antimicrobial agents. Resistance was observed most commonly towards bacitracin 100\%., penicillin 100\%., sulphafurazole 77\%., ampicillin 57\%., cephalothin 53\%., carbenicillin 47\%., ceftazidime $37 \%$ and erythromycin $30 \%$.

Phenicols group prevent protein chain elongation by inhibiting the peptidyl transferase activity of the bacterial ribosome. Chloramphenicol (and thiamphenicol) resistance is mainly due to enzymatic modification by chloramphenicol acetyltransferases (CAT). These enzymes covalently link an acetyl group from acetylCoA to chloramphenicol, preventing it from binding to the ribosomes, and arengrouped into two types, A and B. However, these enzymes do not confer resistance to florfenicol. They are encoded by various genes, which have been found on chromosomes, plasmids, transposons, or integrin cassettes (Lambert, 2012)

The second mechanism consists of efflux pumps encoded in Gram-negative bacteria by $\mathrm{cml}$ genes, which confer cross-resistance 
to chloramphenicol and florfenicol (Schwartz et al., 2004). More recently, florfenicol resistance conferred by the floR genes, referred to in the published literature as pp-flo, cmlA-like, floSt, flo, or floR, has also been detected in E. coli (Bischoff et al., 2002).

By examination of 30 E.coli isolate recorded that 29( $96 \%$ ) of isolate were carry florfenicol resistance against (floR) gene table (3)and figure (3), agree with Jing et al., (2013) who detected the prevalence offloR gene in chickens E.coli strain. It noticed that there was an increased gradually from (2007-2012). On other hand Xin et al., (2007) reported the genetic mechanisms relevant to florfenicol resistance in the chicken E.coli isolates were evaluated for the presence of 5 genes recognized to confer resistance to these antimicrobials: $\mathrm{cmlA}$, cat-1, cat-2, cat-3, and floR. The total genomic DNA was found in thirteen $E$. coli isolates $(18.6 \%)$ which were positive for the floR gene .Also $53.3 \%$ resistance to florfenciol antibiotic among 30isolate in our study by using disc diffusion. Xin et al., (2007) observed that about $29 \%$ of E.coli isolate was resistance to florfenicol in order to ensure the rational and effective use of these drugs. Bacteria could use three strategies to become resistant to tetracycline: limiting the access of tetracycline to the ribosomes, altering the ribosome to prevent effective binding of tetracycline, and producing tetracyclineinactivating enzymes. All three types of resistance have been found in clinical isolates. With the discovery of so many tetracycline resistance genes in recent years, a classificationscheme had to be devised .The current convention is to assign a resistance gene to a particular class on the basis assign a resistance gene to a particular class on the basis of DNA-DNA hybridization with members of that class (Levey 1988). Tetracycline inhibits bacterial protein synthesis and affects bacterial cell wall (Chopra and Roberts, 2001). Tetracycline resistance due to target modification is mediated by ribosomal protection proteins (RPP) that represent a widely distributed class of resistance genes (Thaker et al., 2010). E.coli isolate were resistance to tetracycline (tetA) gene (73\%). Figure (4) and table (3). Also Soufi et al., (2011) analyzed the resistance of 166 E. coli isolates recovered from poultry in Tunisia. High percentages of resistance were detected totetracycline $95.2 \%$; ampicillin $65.7 \%$; streptomycin $69.3 \%$; nalidixic acid $72.3 \%$; and sulphonamide $81.9 \%$ while Moon et al., (2011) amplified tetA resistance gene from chicken was about $20.2 \%$. Most of isolates was resistance to tetracycline antibiotic with $80 \%$ by disc diffusion table (2) agree with Moon et al., (2011) who studied the actual frequency of antimicrobial resistance in fecal E.coli isolated from chicken. One hundred and nine $E$. coli isolates were higher resistant to tetracycline (96.3\%), ampicillin (68.8\%) streptomycin $(60.6 \%)$ and ciprofloxacin (65.1\%). On other hand Radu et al., (2001) showed few strains were resistant to tetracycline $7 \%$, streptomycin $17 \%$, nalidixic acid $13 \%$, chloramphenicol $10 \%$, latamoxef $7 \%$ and kanamycin 7\%, Aminoglycosides primarily act by binding to the 16S rRNA that recognizes the aminoacyl-tRNA; this action inhibits bacterial protein synthesis (Magnet and Blanchard, 2004). Target modification by ribosomal mutations or enzymatic modifications of ribosomal components inhibits the action of aminoglycosides (Davies and Wright, 1997). A number of actinomycetes that produce aminoglycosides also produce $16 \mathrm{~S}$ rRNA methylases that protect them from the inhibitory effects of the antibiotic (Magnet and Blanchard, 2004). Among six antibiotics which used in these study found that 30 E.coli isolates showed lower percentage against $(\mathrm{aad} \mathrm{B})$ gentamicin resistance gene in $8(26 \%)$ as shown in figure (5) and table (3) agree with Kim et al., (2007), who found about $26.7 \%$ of E.coli isolate was resistance to gentamicin while Minh et al., (2009) obtained multidrug resistance isolated from Niger 
Native $58.6 \%$ which were resistance to gentamicin. By disc diffusion (46.6\%) of E.coli isolate resistance to gentamicin as showed in table (2) disagree with Soufi, (2009) who recorded $2 \%$ resistant to gentamicin among fifty five E.coli isolate. Gentamicin resistance may be due to the inclusion of this antibiotic with the Marek's vaccine that is administered to almost all poultry inovo vaccination Ricks et al., (1999). Macrolides, lincosamides and streptogramin sarecompounds that are distinct structurally but share a common mode of action and show similar antibacterial spectra, including staphylococci, streptococci, mycoplasmas and campylobacters (Leclercq, 2010). These antibiotics are produced by Streptomycetes by means of various types of polypeptide synthase. Macrolides are classified on the basis of the number of atoms in the ring of the macrocyclic lactone (Schwartz et al (2004), to which are attached deoxy sugars (desosamine and cladinose). Erythromycin resistance gene $m p h(\mathrm{~A})$ was found in $36 \%$ of E.coli isolate fig(6) and table(3), while Goswami et al., (2002) showed that lower percentage of E.coli isolate resistance to erythromycin (7.84). By dis diffusion $63.3 \%$ of E.coli isolate resistance to erythromycin antibiotic among 30 E.coli isolate table (2) .On otherhand, Makhol et al., (2011) demonstrated that $100 \%$ of all tested isolates of E.coli strains isolated from poultry were resistant to erythromycin. The resistance mechanism of $E$. coli is complicated. The resistance genes mediated by plasmid can make the resistance spread among different bacteria, which make bacteria obtain resistance genes more easily and thus produce multiple resistances.

Conclusion: Multidrug resistant bacteria were detected by traditional and techniques and conformed by detection of gene responsible for that resistance .Great attention should begiven to use antibiotics in poultry farms.

\section{REFERENCES}

Abraham, E.P. 1940. Chain E An enzyme from bacteria able to destroy penicillin. Nature, 146:837

Ahmed, M.M., Soad, A.N., El-Hariri, M, Refai, M. 2014. Detection of PlasmidMediated Quinolone and $\beta$-lactam Resistant Genes in Escherichia Coli Isolates from Diseased Poultry in Egypt. International Journal of Advanced Research 2(5):75

Al Ghamdi, M.S., El Morsy, F., Al Mustafa, Z.H., Al Ramadhan, M., Hanif, M. 1999. Antibiotic resistance of Escherichia coli isolated from poultry workers, patients and chicken in the eastern province of Saudi Arabia. Tropi. Med. and Inter. Heal., 4:278283.

Amara, A., Ziani, Z., Bouzoubaa, K. 1995.Antibioresistance of E. coli strains isolated in Morocco from chickens with colibacillosis. Vet. Microbiol, 43: 325-330

Andriole, V.T. 2005. The quinolones: past, present, and future. The Infec. Dis. Soc. Amer., 41:5113-5119

Barnes, H.J, Gross, W.B. 1997. Colibacilosis in: Calnek, B.W. (Ed).Disease of poultry. $10^{\text {th }} \mathrm{Ed}$. University Press, Ames, Iowa State, 131-141.

Brinas, L., Moreno, M.A., Zarazaga, M., Porrero, C., Sa'enz, Y., García, M., Dominguez, L., Torres, C. 2003. Detection of $C M Y-2, C T X-M-14$, and $S H V-12 \beta$-Lactamases in Escherichia coli fecal-sample isolates from healthy chickens. Antimicrob. Agents Chemother., 47(6):2056-2058.

Bischoff, K.M, White, D.G, McDermott, P.F, Zhao. S, Gaines, S., Maurer, J.J, Nisbet, D.J. 2002. Characterization of chloramphenicol resistance in betahemolytic Escherichia coli associated with diarrhea in neonatal swine. J ClinMicrobiol, 40:389 -394.

Chopra,I.,Roberts, M. 2001 .Tetracycline antibiotics: mode of action, applications, molecular biology and epidemiology of bacterial resistance. 
Microbiol. Mol. Biol. Rev., 65:232260.

Cooke, E.M., Breaden, A.L., Shooter, R.A., O'Farrell, S.M. 1971. Antibiotic sensitivity of Escherichia coli isolated from animals, food, hospital patients, and normal people. Lancet, 2: 8-10.

Colom, K., Pèrez, J., Alonso, R., Fernández-Aranguiz, A., Lariňo, E., Cisterna, R. 2003. Simple and reliable multiplex PCR assay for detection of bla TEM, bla SHV and blaOXA-1 genes in Enterobacteriaceae. FEMS Microb. Let., 223:147-151.

Cruickshank, H., Duguid, J., Marmon, B.P., Swain, R.H.A. 1975. Medical Microbiology. The practice of Medical Microbiology, Vol.150, $12^{\text {th }}$ Ed. Churchill Livingstone, Edinburgh. London and New York.

Davies, J., Wright, G.D. 1997. Bacterial resistance to aminoglycoside antibiotics. Trends Microbiol, 5:234240

Domínguez, E., Zarazaga, M., Sáenz, Y., Briñas, L., Torres, C. 2002. Mechanisms of antibiotic resistance in Escherichia coli isolates obtained from healthy children in Spain. Microb. Drug Resist. 8(4):321-327.

Doublet, B., Lailler, R., Meunier, D., Brisabois, A., Boyd, D., Mulvey, M.R., Chaslus-Dancla, E., Cloeckaert, A. 2003. Variant Salmonella Genomic Island 1 Antibiotic Resistance Gene Cluster in Salmonella enteric Serovar Albany. Emerg. Inf. Diseases., 9(5): 585-591

Frana, T.S., Carlson, S. A., Griffith, R. W. 2001. Relative distribution and conservation of genes encoding aminoglycoside-modifying enzymes in Salmonella enterica serotype Typhimurium phage type DT104. App-Enviro. Microbio., 67:445-448.

Geornaras, I., Hastings, J. W., Von Holy, A. 2001. Genotypic analysis of $E$. coli strains from poultry carcasses and their susceptibility to antimicrobial agents. Appl. Environ. Microbiol., 67: 1940-1944.

Goswami, P., Hui, A.K., Das, R., Kolkata, Chakrabarti, A.2002. Isolation, identification and antibiogram of Escherichia coli from poultry in field condition. J. Interacademicia, 6(1):680-683.

Jiang, H., Lü, D., Chen, Z., Wang, X., Chen, J., Liu, Y., Liao, X., Liu, J., Zeng, Z. 2011. High prevalence and widespread distribution of multiresistant Escherichia coli isolates in pigs and poultry in China. Vet. J., 187: 99-103

Jing-Yu Wang, Pan Tang, En-Hui Cui, LiQin Wang, Wan-Hua Liu, Juan-Juan Ren, Ning Wu, Yuan-HaoQiu., HungJen Liu. 2013. Characterization of antimicrobial resistance and related resistance genes in Escherichia coli strains isolated from chickens in China during 2007-2012

Kaul, L., Kaul, L.P., shah, N.M. 1992. An outbreak of colibacillosis in chicks at an organized poultry farmunder semiarid zone of north Gujarat. Indian. Vet. J., 69:373-374.

Kim, T., Jeong, Y., Cho, S., Kim, S. , Kwon, H. 2007. Chronological study of antibiotic resistances and their relevant genes in Korean avian pathogenic Escherichia coli isolates. J. Clin. Microbiol., 45(10):33093315.

Lambert, T. 2012. Antibiotics that affect the ribosome .Rev. sci. tech. off. int. Epiz., 31(1):57-64

Leclercq, R. 2010.Macrolides, lincosamides, and streptogramins In Antibiogram (P. Courvalin, R. Leclercq\& L. Rice, eds). ESKA, Portland, Oregon, 305- 326.

Levy, S. B. 1988. Tetracycline resistance determinants arewidespread. ASM News 54:418-421.

Levy, S.B., FitzGerald, G.B., Macone, A.B. 1976. Spread of antibiotic-resistant plasmids from chicken to chicken and from chicken to man. Nat., 260:40-2. 
Linton, A.H., Howe, K., Bennett, P.M., Richmond, M.H., Whiteside, E.J. 1977. The colonization of the human gut by antibiotic resistant Escherichia coli from chickens. J. Appl. Bacteriol., 43:465-469.

Lunn, A.D., Fàbrega, A., SánchezCéspedes, J., Vila, J. 2010. Prevalence of mechanisms decreasing quinolonesusceptibility among Salmonella spp. clinical isolates. Int. Microbio. 13:1520

Magnet, S. Blanchard, J.S. 2004. Molecular Insights into Aminoglycoside Action and Resistance. Chem Rev, 105:477498.

Makhol, B. M., Habreh, N., Sakural, K. 2011. Antibiotic resistance of E.coli isolated from poultry in Syria. Assiut Vet. Med. J. 57(128):265-275.

'Moon Ho Jang, 'Jae Keun Cho, iDongMiKwak, 'Gil-Jae Cho,'Young Ju Lee 2011.Antimicrobial Resistance and Resistance Gene Determinants of Fecal Escherichia coli Isolated from Chicken. Korea J-Anim-Vet-Adv., 10(24):3308-3311

Nguyen, M.C.P., Woerther, P., Bouvet, M., Andremont, A., Leclercq, R., Canu, A. 2009. Escherichia coli as reservoir for macrolide resistance genes. Emerg. Inf. dis. 15(10):1648-1650

Nordmann, P., Poirel, L. 2005. Emergence of plasmid-mediated resistance to quinolones in Enterobacteriaceae. J. of Antimicrob.Chemoth., 56: 463469

Ojeniyi, A.A. 1985. Comparative bacterial drug resistance in modern battery and free-range poultry in a tropical environment. Vet. Rec., 117:121.

Ojeniyi, A.A. 1989. Direct transmission of Escherichia coli from poultry to humans. Epidemiol.Infec., 103:51322.

Radu, S., Ling, O. W., Rusul, G., Abdul Karim, M.I., Nishibuchi, M. 2001. Detection of Escherichia coli O157:H7 by multiplex PCR and their characterization by plasmid profiling, antimicrobial resistance, RAPD and PFGE analyses. J. Microbiol. Methods, 46:131-139.

Randall, L.P., Cooles, S.W., Osborn, M.K., Piddock, L.J.V., Woodward, M.J. 2004. Antibiotic resistance genes, integrons and multiple antibiotic resistances in thirty-five serotypes of Salmonella enteric isolated from humans and animals in the UK J. Antimicrobial. Chem. 53:208-216.

Ricks, C.A., Avakian, A., Bryan, T., Gildersleeve, R., Haddad, E., Ilich, R., King, S., Murray, L., Phelps, P., Poston, R., Whitfill, C., Williams, C. 1999. In ovo vaccination technology. Adv. Vet. Med. 41:495-515

Saif, Y.M. 2003.Disease of poultry.11th edition.Lowa State press, A Black well publishing company. PP. 631652

Sambrook, J., Fritsch, E.F., Maniatis, T. 1989. Molecular cloning. A laboratory manual. $2^{\text {nd }}$ Edition. Cold Spring Harbor, N.Y

Schwartz, S., Kehrenberg, C., Doublet B., Cloeckaert, A. 2004. Molecular basis of bacterial resistance to chloramphenicol and florfenicol. FEMS Microbiol. Rev., 28:519-542

Singh, M., Chaudhry, M.A., Yadava, J.N.S., Sanyal, S.C. 1992. The spectrum of antibiotic resistance in human and veterinary isolates of Escherichia coli collected from 198486 in Northern India. J. Antimicrobial. Chemother., 29:159-168

Soufi, L., Abbassi, M.S., Saenz, Y., Vinué, L., Somalo, S., Zarazaga, M., Abbas, A., Dbaya, R., Khan fir, L., Ben Hassan, A., Hammami, S., Torres, C. 2009. Prevalence and diversity of integrons and associated resistance genes in E.coli isolates from poultry meat in Tunisia. Fodborne Pathog. Dis. 6(9): 1067-1073

Thaker, M.P., Spanogiannopoulos, G.D., Wright 2010. The tetracycline resistance. Cell/Molecular Life Sci., 67:419-43 
Van den Bogaard, A.E., London, N., Driessen, C., Stobberingh, E.E. 2001. Antibiotic resistance of faecal Escherichia coli in poultry, poultry farmers and poultry slaughterers. J. Antimicrob. Chemother., 47:763771.

Wang, H., Dzink-fox, J.L., chen, M,levy, S.B. 2001. Genetic characterization of highly fluoroquinolone resistant clinical Escherichia coli strains from China: Role of acrR Mutations. Antimicrob. Agents Chemother., 24(5):1515-1521.

Xia, L., Li, L., Wu, C., Liu, Y., Tao, X., Dai, L., Qi, Y., Lu, L., Shen, J. 2009. A survey of plasmid mediated fluoroquinolone resistance genes from Escherichia coli isolates and their dissemination in Shandong, China. Foodborne Path. Dis. 207-215

Xin-Sheng Li, Gui-Qin Wang, Xiang-Dang Du, Bao-An Cuil, Su-Mei Zhang1, Jian-Zhong Shen. 2007. Antimicrobial susceptibility and molecular detection of chloramphenicol And florfenicol resistance among Escherichia coli isolates from diseased chickens .Department of Pharmacology and Toxicology, College of Veterinary Medicine, China Agricultural University, Beijing 100094, P.R. China. 